\title{
K-MEANS CLUSTERING UNTUK DATA KECELAKAAN LALU LINTAS JALAN RAYA DI KECAMATAN PELAIHARI
}

\author{
Winda Aprianti ${ }^{1}$, Jaka Permadi ${ }^{2}$ \\ ${ }^{1,2}$ Jurusan Teknik Informatika, Politeknik Negeri Tanah Laut \\ Email: ${ }^{1}$ winda@ @olitala.ac.id, ${ }^{2}$ jakapermadi.88@politala.ac.id
}

(Naskah masuk: 10 Oktober 2018, diterima untuk diterbitkan: 24 Oktober 2018)

\begin{abstract}
Abstrak
Kecelakaan lalu lintas di jalan raya masih menjadi penyumbang tingginya angka kematian di Indonesia, sehingga menjadi perhatian khusus bagi kepolisian di negara ini. Termasuk Kepolisian Resor (Polres) Tanah Laut, yang telah membuktikan perhatian tersebut dengan membentuk komunitas korban kecelakaan lalu lintas dan Pelatihan Pertolongan Pertama Gawat Darurat (PPGD). Tahapan awal pencegahan kecelakaan lalu lintas adalah dengan mengetahui faktor-faktor penyebab kecelakaan lalu lintas yang diperoleh melalui analisa data kecelakaan. Analisa tersebut dapat dilakukan dengan data mining, yaitu K-Means Clustering. K-Means Clustering mengelompokkan data menjadi beberapa cluster sesuai karakteristik data tersebut. Data kecelakaan lalu lintas dibagi menjadi 2 dataset, yakni dataset 1 dan dataset 2. Hasil cluster penerapan $K$-means clustering terhadap dataset 1 dan dataset 2 kemudian dilakukan pengujian silhoutte coefficient untuk mencari hasil cluster dengan kualitas terbaik. Pengujian silhoutte coefficient secara berurutan menghasilkan distance measure paling optimal yakni clustering dengan 4 cluster untuk dataset 1 dan clustering dengan 2 cluster untuk dataset 2. Selain memperoleh cluster dengan kualitas terbaik, penganalisaan data juga menghasilkan beberapa informasi kecelakaan lalu lintas yang sering terjadi, yakni faktor penyebab dan korban kecelakaan adalah pengemudi, umur korban adalah 9 sampai 28 tahun, dan keadaan korban kecelakaan adalah luka ringan.
\end{abstract}

Kata kunci: k-means, clustering, kecelakaan, lalu lintas, silhoutte coefficient

\section{K-MEANS CLUSTERING FOR HIGHWAY TRAFFIC ACCIDENT DATA IN PELAIHARI SUB DISTRICT}

\begin{abstract}
Traffic accidents on the highway are still contribute to the high mortality rate in Indonesia, which are becoming a special concern for the police. Including the Police of Tanah Laut Resort where prove themselves by established The Community of Traffic Accident Victims and Emergency First Aid Training. The first prevention of traffic accidents is knowing the factors causing traffic accidents which is obtained through the analysis of traffic accident's data. It can be done through data mining, i.e. K-Means Clustering, which is clustering data into clusters according to characteristics of the data. Traffic accident data is divided into two datasets, namely dataset 1 and dataset 2. After obtaining the cluster results, the next step is to calculate silhoutte coefficient which is used to find the best quality cluster result. The result of testing silhoutte coefficient are clustering with 4 clusters for dataset 1 and clustering with 2 clusters for dataset 2. Analyzing data in this research also produces some information on traffic accidents that often occur, namely the causes and victims of accidents are drivers, the age of the victims is between 9 and 28 years old, and the circumstance of the accidents victims are minor injuries.
\end{abstract}

Keywords: $k$-means, clustering, accident, traffic, silhoutte coefficient

\section{PENDAHULUAN}

Kecelakaan lalu lintas di jalan raya masih menjadi penyumbang angka kematian yang relatif tinggi di Indonesia. Hal ini didukung dengan data yang dikeluarkan oleh Korps Lalu Lintas Kepolisian Republik Indonesia (Korlantas Polri), trend kecelakaan lalu lintas di Indonesia mengalami penurunan menjadi 95.906 kasus pada tahun 2014 dan kembali mengalami peningkatan menjadi 105.374 kasus dengan 25.859 korban meninggal pada tahun 2016 (Maulana, 2017). Kecelakaan lalu lintas juga menjadi permasalahan di Provinsi Kalimantan Selatan. Data yang bersumber dari PT Jasa Raharja Cabang Kalimantan Selatan 
menyatakan bahwa kecelakaan yang terjadi pada tahun 2014 berjumlah 963 kasus. Pada tahun 2016 periode Januari sampai dengan Agustus telah terjadi 7 kasus kecelakaan lau lintas di Kabupaten Tanah Laut (Wahid, 2016). Kecelakaan lalu lintas merupakan hal yang menjadi perhatian khusus oleh Kepolisian Resor (Polres) Tanah Laut dibuktikan dengan dibentuknya komunitas korban kecelakaan lalu lintas dan pelatihan pertolongan pertama gawat darurat (PPGD) sebagai salah satu upaya dalam mengurangi angka kecelakaan dan fatalitas korban (Humas Polres Tanah Laut, 2017).

Berdasarkan data yang telah diuraikan maka perlu analisis lebih lanjut terhadap permasalahan kecelakaan lalu lintas untuk mengetahui faktorfaktor penyebab kecelakaan lalu lintas. Analisa terhadap data kecelakaan dapat dilakukan menggunakan data mining, yakni K-Means clustering yang dapat mengklasifikasikan data menjadi beberapa cluster sesuai karakteristik data. Penerapan K-Means clustering untuk analisa daa kecelakaan telah dilakukan oleh Iswari (2015), Fajar (2015), serta Rahmat dkk (2017). Iswari (2015) memanfaatkan algoritma $K$-Means untuk pemetaan daerah rawan kecelakaan di Sleman, Daerah Istimewa Yogyakarta. Rahmat dkk (2017) mengimplementasikan K-Means Clustering untuk menganalisis frekuensi tingkat kecelakaan di tiap lokasi yang berpotensi terjadi kasus kecelakaan di Kota Kendari. Iswari dan Rahmat mengklasifikasikan data kecelakaan lalu lintas menjadi beberapa cluster berdasarkan daerah rawan kecelakaan. Fajar (2015) dalam penelitiaannya juga menggunakan $K$-Means untuk mengklasifikasikan data kecelakaan di Semarang menjadi beberapa cluster kategori tingkat kecelakaan berdasarkan umur korban kecelakaan.

Penerapan K-Means Clustering pada data kecelakaan lalu lintas pada penelitian ini akan menyediakan fitur penginputan data kecelakaan, pemilihan kategori klasifikasi, penentuan centroid awal, pemprosesan K-Means Clustering, dan menampilkan cluster yang dihasilkan. Kemudian akan dilakukan analisa terhadap cluster yang dihasilkan untuk membantu pengurangan resiko terjadinya kecelakaan di Kecamatan Pelaihari Kabupaten Tanah Laut.

Tujuan yang akan dicapai pada penelitian ini adalah mengetahui faktor penyebab, lokasi yang menjadi daerah rawan kecelakaan, korban, usia dan keadaan korban yang paling sering mengalami kecelakaan lalu lintas, serta menerapkan $K$-Means Clustering pada data kecelakaan lalu lintas sehingga dapat memprediksi waktu terjadinya kecelakaan lalu lintas di Kecamatan Pelaihari Kabupaten Tanah Laut.

\section{METODE PENELITIAN}

Tahap pertama pada penelitian ini adalah pengumpulan data, yakni data sekunder dari Polisi
Resort Kabupaten Tanah Laut pada Tahun 2016 dan 2017 Adapun data yang dijadikan objek penelitian ada 9 atribut, yakni lokasi kecelakaan; usia korban kecelakaan; jenis kendaraan meliputi kendaraan roda 2, kendaraan roda 4, dan kendaraan roda lebih dari 4; penyebab terjadinya kecelakaan meliputi pengemudi, lingkungan, jalan, kendaraan; keadaan korban kecelakaan meliputi meninggal, luka berat, dan luka ringan; jumlah kendaraan yang terlibat; korban kecelakaan meliputi pengemudi, penumpang, dan pejalan kaki; hari terjadinya kecelakaan meliputi hari kerja, hari libur, dan akhir minggu; serta waktu terjadinya kecelakaan meliputi dini hari, pagi hari, siang hari, sore hari dan malam hari.

Setelah pengumpulan data dilakukan, tahapan selanjutnya adalah preprocessing data meliputi selection data dan transformation data. Selection data merupakan proses pemilihan beberapa faktor yang memuat informasi utama untuk dijadikan atribut clustering. Sedangkan tranformation data merupakan proses pengubahan data dari bentuk deskriptif ke bentuk tipe data nominal. Data hasil preprocessing kemudian dikelompokkan menggunakan K-Means Clustering dengan penentuan centroid awal menggunakan metode simple random sampling. Setelah memperoleh cluster dari data kecelakaan, maka akan dihitung Silhouette Coefficient untuk mengetahui kualitas dan kekuatan cluster (Anggara dkk, 2016 dan Anggodo $\mathrm{dkk}, 2017)$. Tahap terakhir adalah melakukan analisa terhadap cluster yang dihasilkan.

\section{HASIL DAN PEMBAHASAN}

Data kecelakaan yang diperoleh dari Polisi Resort Kabupaten Tanah Laut pada Tahun 2016 dan 2017 berjumlah 32 data dimana setiap data memuat 9 atribut. Berdasarkan data sekunder tersebut diperoleh bahwa penyebab kecelakaan lalu lintas adalah pengemudi. Selain itu, diperoleh juga informasi mengenai korban, usia korban, dan keadaan yang paling sering dialami korban pada kecelakaan lalu lintas di Kecamatan Pelaihari.

Visualisasi data kecelakaan awal disajikan pada Gambar 1.

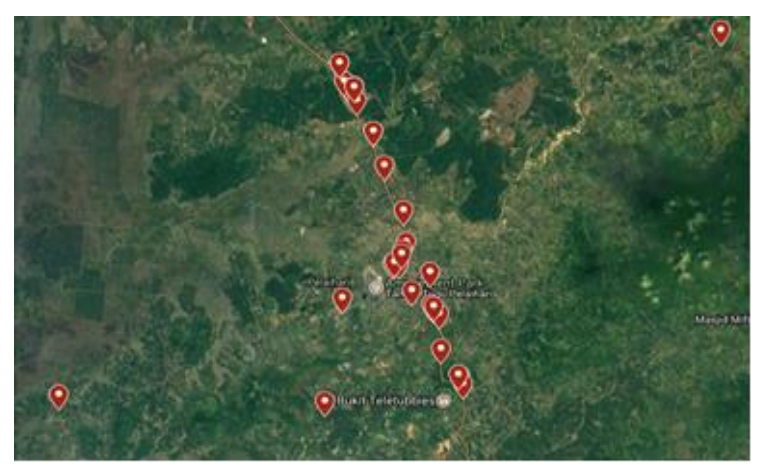

Gambar 1. Visualisasi Data Kecelakaan Lalu Lintas

Sedangkan informasi mengenai hal yang disebutkan di atas disajikan pada Gambar 2. 


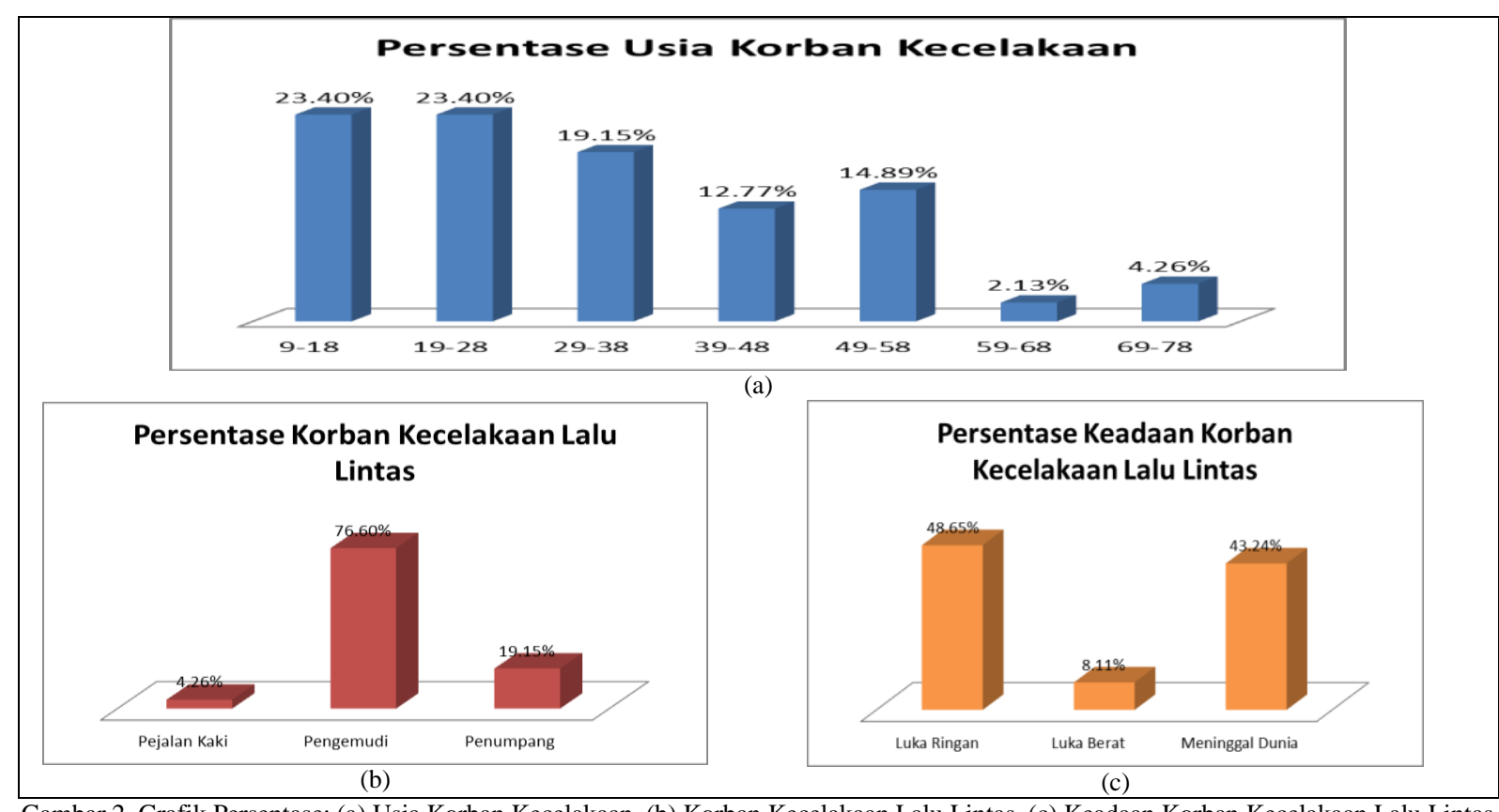

Gambar 2 menunjukkan kecelakaan lalu lintas sering terjadi pada usia kelompok 9-18 tahun dan 19-28 tahun, korban kecelakaan sering kali adalah pengemudi kendaraan, dan keadaan yang dialami korban kecelakaan yang paling sering adalah luka ringan tetapi perbedaan persentase dengan keadaan korban yang meninggal dunia tidak berbeda jauh, yakni hanya berbeda $5.41 \%$.

Guna menggali informasi lebih lanjut, maka diterapkan algoritma K-Means Clustering terhadap data yang telah dilakukan preprocessing. Tahap awal preprocessing adalah selection data. Data yang dikumpulkan menunjukkan faktor penyebab terjadinya kecelakaan hanya disebabkan pengemudi maka faktor ini dihapuskan dari atribut clustering maka pada tahapan selection data diperoleh 8 atribut clustering. Data ini kemudian ditransformasi ke bentuk nominal sehingga diperoleh dataset 1 yang ditampilkan pada Tabel 1 dan dataset 2 yang ditampilkan pada Tabel 2 .

Tabel 1 menyajikan dataset 1 yang memuat data lokasi kejadian dalam koordinat lattitude dan longitude.

Tabel 1. Dataset Awal untuk Lokasi Kejadian

\begin{tabular}{cccccc}
\hline \multicolumn{7}{c}{ Tabel 1. Dataset Awal untuk Lokasi Kejadian } \\
\hline ID & Lattitude & Longitude & ID & Lattitude & Longitude \\
\hline lap_01 & -3.81597 & 114.78542 & lap_17 & -3.71626 & 114.75082 \\
lap_02 & -3.72637 & 114.75423 & lap_18 & -3.79004 & 114.77582 \\
lap_03 & -3.73156 & 114.75729 & lap_19 & -3.80225 & 114.78481 \\
lap_04 & -3.81925 & 114.78816 & lap_20 & -3.79884 & 114.77066 \\
lap_05 & -3.74428 & 114.76335 & lap_21 & -3.81646 & 114.78601 \\
lap_06 & -3.84506 & 114.7962 & lap_22 & -3.81273 & 114.75173 \\
lap_07 & -3.74445 & 114.76345 & lap_23 & -3.77673 & 114.77485 \\
lap_08 & -3.85549 & 114.74524 & lap_24 & -3.79298 & 114.77462 \\
lap_09 & -3.72397 & 114.75256 & lap_25 & -3.85256 & 114.64546 \\
lap_10 & -3.7988 & 114.77327 & lap_26 & -3.79807 & 114.77154 \\
lap_11 & -3.7029 & 114.89416 & lap_27 & -3.72608 & 114.75615 \\
lap_12 & -3.81555 & 114.785 & lap_28 & -3.83383 & 114.78884 \\
lap_13 & -3.91452 & 114.63109 & lap_29 & -3.84828 & 114.79734 \\
lap_14 & -3.72577 & 114.75623 & lap_30 & -3.79463 & 114.77399 \\
lap_15 & -3.80972 & 114.77807 & lap_31 & -3.84438 & 114.79537 \\
lap_16 & -3.71626 & 114.75082 & lap_32 & -3.75838 & 114.76751 \\
\hline
\end{tabular}

Tabel 2 menyajikan dataset 2 yang memuat 7 atribut, yakni umur korban (A); jumlah kendaraan yang terlibat (B); jenis kendaraan meliputi kendaraan roda $2(\mathrm{C} 1)$, kendaraan roda $4(\mathrm{C} 2)$, dan kendaraan roda lebih dari 4 (C3); korban kecelakaan meliputi pejalan kaki (D1), pengemudi (D2), dan penumpang (D3); hari terjadinya kecelakaan meliputi hari kerja (E1), hari libur (E2), dan akhir minggu (E3); waktu terjadinya kecelakaan meliputi pagi hari (F1), siang hari (F2), sore hari (F3), malam hari (F4), dan dini hari (F5); serta keadaan korban kecelakaan meliputi luka ringan (G1), luka berat (G2), dan meninggal dunia (G3). 
616 Jurnal Teknologi Informasi dan Ilmu Komputer (JTIIK), Vol. 5, No. 5, Oktober 2018, hlm. 613-620

\begin{tabular}{|c|c|c|c|c|c|c|c|c|c|c|c|c|c|c|c|c|c|c|c|}
\hline No & $\mathbf{A}$ & B & C1 & C2 & C3 & D1 & D2 & D3 & E1 & E2 & E3 & F1 & F2 & F3 & F4 & F5 & G1 & G2 & G3 \\
\hline 1 & 9 & 1 & 0 & 0 & 0 & 1 & 0 & 0 & 1 & 0 & 0 & 0 & 1 & 0 & 0 & 0 & 0 & 0 & 1 \\
\hline 2 & 14 & 1 & 1 & 0 & 0 & 0 & 1 & 0 & 0 & 0 & 0 & 0 & 0 & 0 & 0 & 0 & 0 & 0 & 1 \\
\hline 3 & 17 & 5 & 5 & 0 & 0 & 0 & 3 & 2 & 0 & 0 & 1 & 1 & 0 & 0 & 0 & 0 & 2 & 2 & 1 \\
\hline 4 & 18 & 4 & 4 & 0 & 0 & 0 & 3 & 1 & 3 & 0 & 0 & 1 & 0 & 1 & 1 & 0 & 2 & 0 & 2 \\
\hline 5 & 22 & 2 & 2 & 0 & 0 & 0 & 2 & 0 & 2 & 0 & 0 & 2 & 0 & 0 & 0 & 0 & 2 & 0 & 0 \\
\hline 6 & 24 & 1 & 0 & 0 & 1 & 0 & 1 & 0 & 0 & 0 & 0 & 0 & 0 & 0 & 0 & 0 & 1 & 0 & 0 \\
\hline 7 & 25 & 3 & 2 & 0 & 1 & 0 & 2 & 1 & 1 & 0 & 0 & 1 & 0 & 0 & 0 & 0 & 2 & 0 & 1 \\
\hline 8 & 26 & 2 & 1 & 1 & 0 & 0 & 2 & 0 & 2 & 0 & 0 & 0 & 0 & 2 & 0 & 0 & 2 & 0 & 0 \\
\hline 9 & 27 & 2 & 0 & 2 & 0 & 0 & 0 & 2 & 0 & 0 & 0 & 0 & 0 & 0 & 0 & 0 & 2 & 0 & 0 \\
\hline 10 & 28 & 1 & 0 & 1 & 0 & 0 & 1 & 0 & 0 & 0 & 0 & 0 & 0 & 0 & 0 & 0 & 0 & 0 & 0 \\
\hline 11 & 29 & 2 & 2 & 0 & 0 & 0 & 2 & 0 & 1 & 0 & 0 & 0 & 0 & 0 & 1 & 0 & 0 & 0 & 2 \\
\hline 12 & 30 & 1 & 0 & 1 & 0 & 0 & 1 & 0 & 0 & 0 & 0 & 0 & 0 & 0 & 0 & 0 & 1 & 0 & 0 \\
\hline 13 & 32 & 1 & 0 & 1 & 0 & 0 & 1 & 0 & 0 & 0 & 0 & 0 & 0 & 0 & 0 & 0 & 0 & 0 & 0 \\
\hline 14 & 35 & 1 & 1 & 0 & 0 & 0 & 1 & 0 & 0 & 0 & 1 & 1 & 0 & 0 & 0 & 0 & 1 & 0 & 0 \\
\hline 15 & 36 & 1 & 0 & 0 & 1 & 0 & 1 & 0 & 0 & 0 & 0 & 0 & 0 & 0 & 0 & 0 & 0 & 0 & 0 \\
\hline 16 & 37 & 2 & 2 & 0 & 0 & 0 & 1 & 1 & 0 & 0 & 0 & 0 & 0 & 0 & 0 & 0 & 0 & 0 & 2 \\
\hline 17 & 38 & 1 & 0 & 1 & 0 & 0 & 1 & 0 & 1 & 0 & 0 & 1 & 0 & 0 & 0 & 0 & 1 & 0 & 0 \\
\hline 18 & 41 & 1 & 0 & 0 & 1 & 0 & 1 & 0 & 0 & 0 & 0 & 0 & 0 & 0 & 0 & 0 & 0 & 0 & 0 \\
\hline 19 & 43 & 1 & 0 & 1 & 0 & 0 & 1 & 0 & 0 & 0 & 0 & 0 & 0 & 0 & 0 & 0 & 0 & 0 & 0 \\
\hline 20 & 45 & 2 & 2 & 0 & 0 & 0 & 1 & 1 & 0 & 0 & 1 & 1 & 0 & 0 & 0 & 0 & 1 & 0 & 1 \\
\hline 21 & 47 & 1 & 1 & 0 & 0 & 0 & 1 & 0 & 0 & 0 & 1 & 0 & 0 & 0 & 1 & 0 & 0 & 0 & 1 \\
\hline 22 & 48 & 1 & 0 & 1 & 0 & 0 & 1 & 0 & 0 & 0 & 0 & 0 & 0 & 0 & 0 & 0 & 0 & 0 & 0 \\
\hline 23 & 49 & 1 & 0 & 1 & 0 & 0 & 1 & 0 & 0 & 0 & 0 & 0 & 0 & 0 & 0 & 0 & 0 & 0 & 0 \\
\hline 24 & 50 & 2 & 2 & 0 & 0 & 0 & 2 & 0 & 1 & 0 & 0 & 0 & 0 & 0 & 0 & 0 & 0 & 0 & 2 \\
\hline 25 & 51 & 2 & 2 & 0 & 0 & 0 & 2 & 0 & 0 & 0 & 0 & 0 & 0 & 0 & 0 & 0 & 0 & 1 & 1 \\
\hline 26 & 53 & 1 & 0 & 1 & 0 & 0 & 0 & 1 & 0 & 0 & 0 & 0 & 0 & 0 & 0 & 0 & 1 & 0 & 0 \\
\hline 27 & 56 & 1 & 0 & 1 & 0 & 0 & 1 & 0 & 0 & 0 & 0 & 0 & 0 & 0 & 0 & 0 & 0 & 0 & 0 \\
\hline 28 & 60 & 1 & 1 & 0 & 0 & 0 & 1 & 0 & 0 & 1 & 0 & 0 & 1 & 0 & 0 & 0 & 0 & 0 & 1 \\
\hline 29 & 70 & 0 & 0 & 0 & 0 & 1 & 0 & 0 & 0 & 0 & 0 & 0 & 0 & 0 & 0 & 0 & 0 & 0 & 1 \\
\hline 30 & 74 & 1 & 1 & 0 & 0 & 0 & 1 & 0 & 0 & 0 & 0 & 0 & 0 & 0 & 0 & 0 & 0 & 0 & 1 \\
\hline
\end{tabular}

Selanjutnya adalah penerapan K-Means Clustering dan perhitungan silhouette coefficient.

\subsection{Hasil K-Means Clusering dan silhouette coefficient pada dataset lokasi kejadian}

Tabel 3 adalah jumlah anggota hasil clustering dari Tabel 1 secara berurutan untuk jumlah kluster sebanyak 2, 3, 4, 5, dan 6 .

\begin{tabular}{|c|c|c|c|}
\hline \multirow{2}{*}{ Cluster } & \multicolumn{2}{|c|}{ Pusat Cluster } & \multirow{2}{*}{$\begin{array}{c}\text { Jumlah } \\
\text { Anggota }\end{array}$} \\
\hline & Lattitude & Longitude & \\
\hline \multicolumn{4}{|c|}{ Jumlah cluster $=2$} \\
\hline 1 & -3.78284 & 114.7755 & 30 \\
\hline 2 & -3.88354 & 114.6383 & 2 \\
\hline \multicolumn{4}{|c|}{ Jumlah cluster $=3$} \\
\hline 1 & -3.88354 & 114.6383 & 2 \\
\hline 2 & -3.72875 & 114.7697 & 11 \\
\hline 3 & -3.81416 & 114.7788 & 19 \\
\hline \multicolumn{4}{|c|}{ Jumlah cluster $=4$} \\
\hline 1 & -3.7029 & 114.8942 & 1 \\
\hline 2 & -3.88354 & 114.6383 & 2 \\
\hline 3 & -3.81416 & 114.7788 & 19 \\
\hline 4 & -3.73134 & 114.7572 & 10 \\
\hline \multicolumn{4}{|c|}{ Jumlah cluster $=5$} \\
\hline 1 & -3.803 & 114.7767 & 14 \\
\hline 2 & -3.84541 & 114.7846 & 5 \\
\hline 3 & -3.73134 & 114.7572 & 10 \\
\hline 4 & -3.7029 & 114.8942 & 1 \\
\hline 5 & -3.88354 & 114.6383 & 2 \\
\hline \multicolumn{4}{|c|}{ Jumlah cluster $=6$} \\
\hline 1 & -3.73134 & 114.7572 & 10 \\
\hline 2 & -3.84541 & 114.7846 & 5 \\
\hline 3 & -3.7029 & 114.8942 & 1 \\
\hline 4 & -3.803 & 114.7767 & 14 \\
\hline 5 & -3.85256 & 114.6455 & 1 \\
\hline 6 & -3.91452 & 114.6311 & 1 \\
\hline
\end{tabular}

Hasil clustering dataset 1 divisualisasikan pada Gambar 3 sampai dengan Gambar 7.

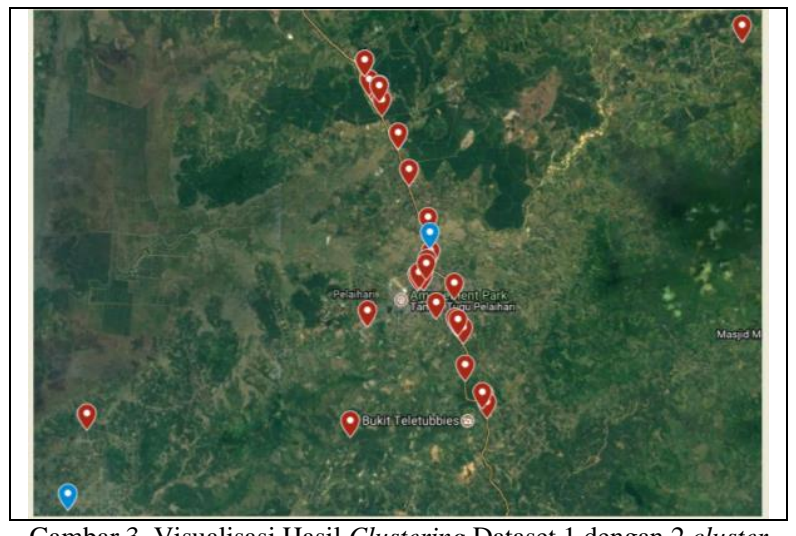

Gambar 3. Visualisasi Hasil Clustering Dataset 1 dengan 2 cluster

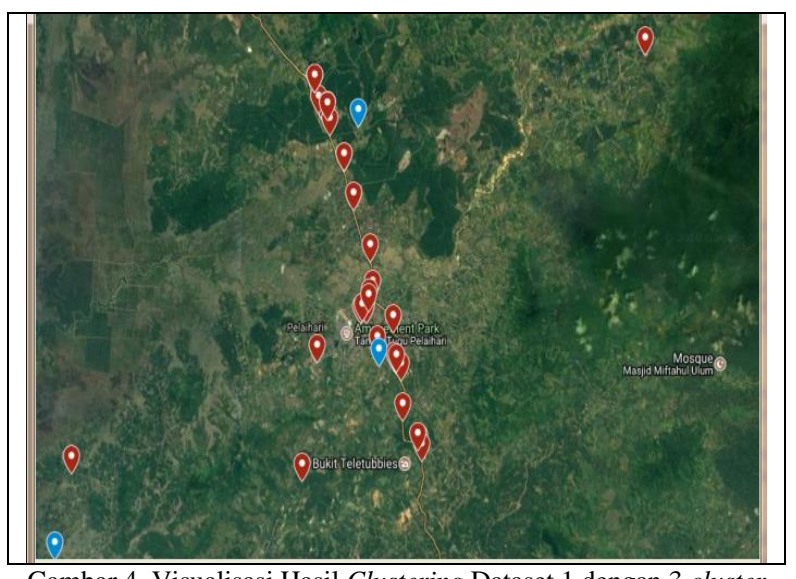

Gambar 4. Visualisasi Hasil Clustering Dataset 1 dengan 3 cluster 


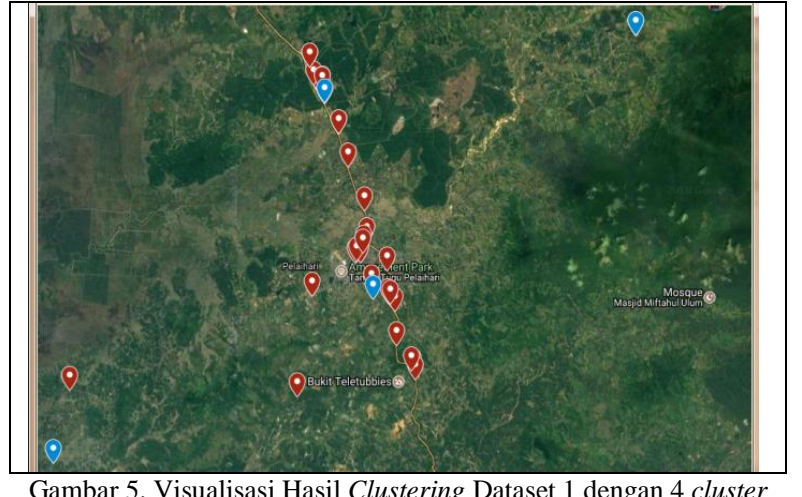

Gamar 5 . Visualisasi Hasil Clustering Dataset 1 dengan 4 cluster

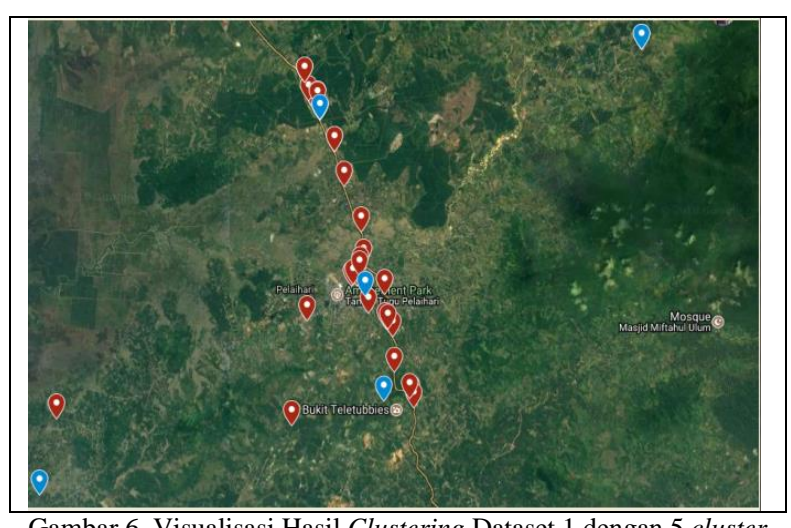

Gambar 6. Visualisasi Hasil Clustering Dataset 1 dengan 5 cluster

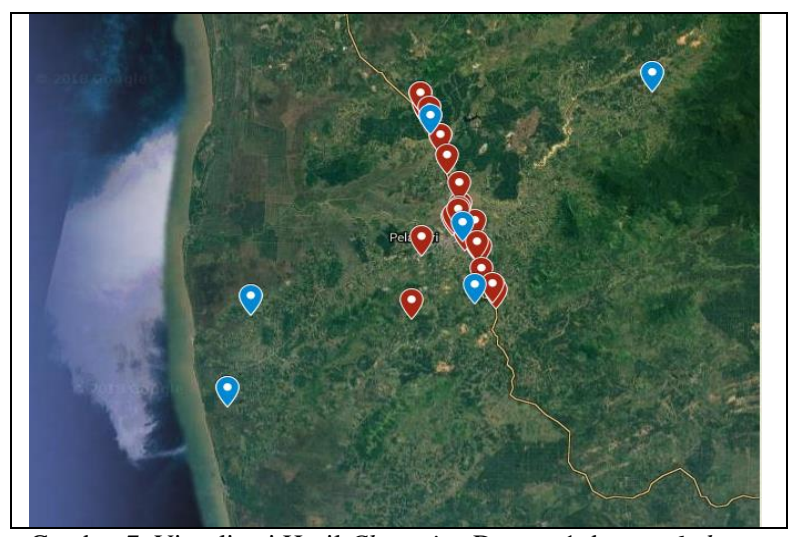

Gambar 7. Visualisasi Hasil Clustering Dataset 1 dengan 6 cluster

Setelah memperoleh cluster dari penerapan $K$ Means, dilakukan pengujian silhouette coefficient pada hasil clustering setiap distance measure untuk menentukan kualitas dan kekuatan cluster. Hasil pengujian dapat dilihat pada Tabel 4.

Tabel 4. Hasil Pengujian Silhouette Coefficient pada Dataset 1

\begin{tabular}{cc}
\hline Jumlah Cluster & Sillhouette Coeficients \\
\hline 2 & 0.610674694 \\
3 & 0.638989160 \\
4 & 0.685351106 \\
5 & 0.633353438 \\
6 & 0.664788553 \\
\hline
\end{tabular}

Hasil pengujian pada Tabel 4 menunjukkan bahwa distance measure paling optimal adalah untuk jumlah cluster sebanyak 4. Hasil clustering akhir untuk jumlah cluster sebanyak 4 untuk dataset 1 disajikan pada Tabel 5.

\begin{tabular}{|c|c|c|c|c|c|c|}
\hline ID & Lattitude & Longitude & $C-1$ & $C-2$ & $C-3$ & $C-4$ \\
\hline lap_01 & -3.81597 & 114.78542 & & & $\mathrm{x}$ & \\
\hline lap_02 & -3.72637 & 114.75423 & & & & $\mathrm{x}$ \\
\hline lap_03 & -3.73156 & 114.75729 & & & & $\mathrm{x}$ \\
\hline lap_04 & -3.81925 & 114.78816 & & & $\mathrm{x}$ & \\
\hline lap_05 & -3.74428 & 114.76335 & & & & $\mathrm{x}$ \\
\hline lap_06 & -3.84506 & 114.7962 & & & $\mathrm{x}$ & \\
\hline lap_07 & -3.74445 & 114.76345 & & & & $\mathrm{x}$ \\
\hline lap_08 & -3.85549 & 114.74524 & & & $\mathrm{x}$ & \\
\hline lap_09 & -3.72397 & 114.75256 & & & & $\mathrm{x}$ \\
\hline lap_10 & -3.7988 & 114.77327 & & & $\mathrm{x}$ & \\
\hline lap_11 & -3.7029 & 114.89416 & $\mathrm{x}$ & & & \\
\hline lap_12 & -3.81555 & 114.785 & & & $\mathrm{x}$ & \\
\hline lap_13 & -3.91452 & 114.63109 & & $\mathrm{x}$ & & \\
\hline lap_14 & -3.72577 & 114.75623 & & & & $\mathrm{x}$ \\
\hline lap_15 & -3.80972 & 114.77807 & & & $\mathrm{x}$ & \\
\hline lap_16 & -3.71626 & 114.75082 & & & & $\mathrm{x}$ \\
\hline lap_17 & -3.71626 & 114.75082 & & & & $\mathrm{x}$ \\
\hline lap_18 & -3.79004 & 114.77582 & & & $\mathrm{x}$ & \\
\hline lap_19 & -3.80225 & 114.78481 & & & $\mathrm{x}$ & \\
\hline lap_20 & -3.79884 & 114.77066 & & & $\mathrm{x}$ & \\
\hline lap_21 & -3.81646 & 114.78601 & & & $\mathrm{x}$ & \\
\hline lap_22 & -3.81273 & 114.75173 & & & $\mathrm{x}$ & \\
\hline lap_23 & -3.77673 & 114.77485 & & & $\mathrm{x}$ & \\
\hline lap_24 & -3.79298 & 114.77462 & & & $\mathrm{x}$ & \\
\hline lap_25 & -3.85256 & 114.64546 & & $\mathrm{x}$ & & \\
\hline lap_26 & -3.79807 & 114.77154 & & & $\mathrm{x}$ & \\
\hline lap_27 & -3.72608 & 114.75615 & & & & $\mathrm{x}$ \\
\hline lap_28 & -3.83383 & 114.78884 & & & $\mathrm{x}$ & \\
\hline lap_29 & -3.84828 & 114.79734 & & & $\mathrm{x}$ & \\
\hline lap_30 & -3.79463 & 114.77399 & & & $\mathrm{x}$ & \\
\hline lap_31 & -3.84438 & 114.79537 & & & $\mathrm{x}$ & \\
\hline lap_32 & -3.75838 & 114.76751 & & & & $\mathrm{x}$ \\
\hline $\begin{array}{l}\text { terangan: } \\
-1=C l u \\
-2=C l u \\
-3=C l u \\
-4=C l u\end{array}$ & & & & & & \\
\hline
\end{tabular}

\subsection{Hasil K-Means Clusering dan silhouette coefficient pada Dataset 2}

$K$-means clustering diterapkan pada Dataset 2 secara berurutan untuk jumlah kluster sebanyak 2, 3, 4, 5, 6, dan 7. Kemudian dilakukan pengujian silhouette coefficient pada hasil clustering setiap distance measure pada jumlah cluster sebanyak 2, 3, 4, 5, 6, dan 7. Hasil pengujian Silhouette Coefficient pada Dataset 2 dapat dilihat pada Tabel 6.

Tabel 6. Hasil Pengujian Silhouette Coefficient pada Dataset 2

\begin{tabular}{cc}
\hline Jumlah Cluster & Sillhouette Coeficients \\
\hline 2 & 0.383686134 \\
3 & 0.316937195 \\
4 & 0.236770018 \\
5 & 0.247250522 \\
6 & 0.277495919 \\
7 & 0.308527071 \\
\hline
\end{tabular}

Tabel 6 menunjukkan bahwa Silhouete Coefficient paling besar adalah pada jumlah cluster 2 , yakni 0.383686134. Dengan kata lain, distance measure paling optimal adalah untuk jumlah cluster sebanyak 2. Hasil clustering akhir untuk jumlah cluster sebanyak 2 disajikan pada Tabel 7 . 
Tabel 7. Hasil Clustering Dataset 2 dengan 2 Cluster

\begin{tabular}{|c|c|c|c|c|c|c|c|c|c|c|c|c|c|c|c|c|c|c|c|c|c|}
\hline No & $\mathbf{A}$ & B & C1 & $\mathrm{C2}$ & C3 & D1 & D2 & D3 & E1 & E2 & E3 & F1 & F2 & F3 & F4 & F5 & G1 & G2 & G3 & Cluster 1 & Cluster 2 \\
\hline 1 & 9 & 1 & 0 & 0 & 0 & 1 & 0 & 0 & 1 & 0 & 0 & 0 & 1 & 0 & 0 & 0 & 0 & 0 & 1 & $\mathrm{X}$ & \\
\hline 2 & 14 & 1 & 1 & 0 & 0 & 0 & 1 & 0 & 0 & 0 & 0 & 0 & 0 & 0 & 0 & 0 & 0 & 0 & 1 & $\mathrm{x}$ & \\
\hline 3 & 17 & 5 & 5 & 0 & 0 & 0 & 3 & 2 & 0 & 0 & 1 & 1 & 0 & 0 & 0 & 0 & 2 & 2 & 1 & & $\mathrm{x}$ \\
\hline 4 & 18 & 4 & 4 & 0 & 0 & 0 & 3 & 1 & 3 & 0 & 0 & 1 & 0 & 1 & 1 & 0 & 2 & 0 & 2 & & $\mathrm{x}$ \\
\hline 5 & 22 & 2 & 2 & 0 & 0 & 0 & 2 & 0 & 2 & 0 & 0 & 2 & 0 & 0 & 0 & 0 & 2 & 0 & 0 & $\mathrm{x}$ & \\
\hline 6 & 24 & 1 & 0 & 0 & 1 & 0 & 1 & 0 & 0 & 0 & 0 & 0 & 0 & 0 & 0 & 0 & 1 & 0 & 0 & $\mathrm{x}$ & \\
\hline 7 & 25 & 3 & 2 & 0 & 1 & 0 & 2 & 1 & 1 & 0 & 0 & 1 & 0 & 0 & 0 & 0 & 2 & 0 & 1 & $\mathrm{x}$ & \\
\hline 8 & 26 & 2 & 1 & 1 & 0 & 0 & 2 & 0 & 2 & 0 & 0 & 0 & 0 & 2 & 0 & 0 & 2 & 0 & 0 & $\mathrm{X}$ & \\
\hline 9 & 27 & 2 & 0 & 2 & 0 & 0 & 0 & 2 & 0 & 0 & 0 & 0 & 0 & 0 & 0 & 0 & 2 & 0 & 0 & $\mathrm{X}$ & \\
\hline 10 & 28 & 1 & 0 & 1 & 0 & 0 & 1 & 0 & 0 & 0 & 0 & 0 & 0 & 0 & 0 & 0 & 0 & 0 & 0 & $\mathrm{x}$ & \\
\hline 11 & 29 & 2 & 2 & 0 & 0 & 0 & 2 & 0 & 1 & 0 & 0 & 0 & 0 & 0 & 1 & 0 & 0 & 0 & 2 & $\mathrm{x}$ & \\
\hline 12 & 30 & 1 & 0 & 1 & 0 & 0 & 1 & 0 & 0 & 0 & 0 & 0 & 0 & 0 & 0 & 0 & 1 & 0 & 0 & $\mathrm{x}$ & \\
\hline 13 & 32 & 1 & 0 & 1 & 0 & 0 & 1 & 0 & 0 & 0 & 0 & 0 & 0 & 0 & 0 & 0 & 0 & 0 & 0 & $\mathrm{X}$ & \\
\hline 14 & 35 & 1 & 1 & 0 & 0 & 0 & 1 & 0 & 0 & 0 & 1 & 1 & 0 & 0 & 0 & 0 & 1 & 0 & 0 & $\mathrm{x}$ & \\
\hline 15 & 36 & 1 & 0 & 0 & 1 & 0 & 1 & 0 & 0 & 0 & 0 & 0 & 0 & 0 & 0 & 0 & 0 & 0 & 0 & $\mathrm{x}$ & \\
\hline 16 & 37 & 2 & 2 & 0 & 0 & 0 & 1 & 1 & 0 & 0 & 0 & 0 & 0 & 0 & 0 & 0 & 0 & 0 & 2 & $\mathrm{x}$ & \\
\hline 17 & 38 & 1 & 0 & 1 & 0 & 0 & 1 & 0 & 1 & 0 & 0 & 1 & 0 & 0 & 0 & 0 & 1 & 0 & 0 & $\mathrm{x}$ & \\
\hline 18 & 41 & 1 & 0 & 0 & 1 & 0 & 1 & 0 & 0 & 0 & 0 & 0 & 0 & 0 & 0 & 0 & 0 & 0 & 0 & $\mathrm{X}$ & \\
\hline 19 & 43 & 1 & 0 & 1 & 0 & 0 & 1 & 0 & 0 & 0 & 0 & 0 & 0 & 0 & 0 & 0 & 0 & 0 & 0 & $\mathrm{x}$ & \\
\hline 20 & 45 & 2 & 2 & 0 & 0 & 0 & 1 & 1 & 0 & 0 & 1 & 1 & 0 & 0 & 0 & 0 & 1 & 0 & 1 & $\mathrm{x}$ & \\
\hline 21 & 47 & 1 & 1 & 0 & 0 & 0 & 1 & 0 & 0 & 0 & 1 & 0 & 0 & 0 & 1 & 0 & 0 & 0 & 1 & $\mathrm{x}$ & \\
\hline 22 & 48 & 1 & 0 & 1 & 0 & 0 & 1 & 0 & 0 & 0 & 0 & 0 & 0 & 0 & 0 & 0 & 0 & 0 & 0 & $\mathrm{X}$ & \\
\hline 23 & 49 & 1 & 0 & 1 & 0 & 0 & 1 & 0 & 0 & 0 & 0 & 0 & 0 & 0 & 0 & 0 & 0 & 0 & 0 & $\mathrm{x}$ & \\
\hline 24 & 50 & 2 & 2 & 0 & 0 & 0 & 2 & 0 & 1 & 0 & 0 & 0 & 0 & 0 & 0 & 0 & 0 & 0 & 2 & $\mathrm{X}$ & \\
\hline 25 & 51 & 2 & 2 & 0 & 0 & 0 & 2 & 0 & 0 & 0 & 0 & 0 & 0 & 0 & 0 & 0 & 0 & 1 & 1 & $\mathrm{x}$ & \\
\hline 26 & 53 & 1 & 0 & 1 & 0 & 0 & 0 & 1 & 0 & 0 & 0 & 0 & 0 & 0 & 0 & 0 & 1 & 0 & 0 & $\mathrm{x}$ & \\
\hline 27 & 56 & 1 & 0 & 1 & 0 & 0 & 1 & 0 & 0 & 0 & 0 & 0 & 0 & 0 & 0 & 0 & 0 & 0 & 0 & $\mathrm{x}$ & \\
\hline 28 & 60 & 1 & 1 & 0 & 0 & 0 & 1 & 0 & 0 & 1 & 0 & 0 & 1 & 0 & 0 & 0 & 0 & 0 & 1 & $\mathrm{x}$ & \\
\hline 29 & 70 & 0 & 0 & 0 & 0 & 1 & 0 & 0 & 0 & 0 & 0 & 0 & 0 & 0 & 0 & 0 & 0 & 0 & 1 & $\mathrm{x}$ & \\
\hline 30 & 74 & 1 & 1 & 0 & 0 & 0 & 1 & 0 & 0 & 0 & 0 & 0 & 0 & 0 & 0 & 0 & 0 & 0 & 1 & $\mathrm{x}$ & \\
\hline
\end{tabular}

Tabel 7 menunjukkan bahwa baik pada cluster 1 maupun cluster 2, kecelakaan lalu lintas sering terjadi pada kendaraan roda 2, korbannya adalah pengemudi, terjadi pada hari kerja, dan terjadi di waktu pagi hari. Namun untuk keadaan korban, pada cluster 1 korban dengan persentase terbanyak adalah meninggal dunia, yaitu 50\%, sedangkan pada cluster 1 korban dengan persentase terbanyak adalah meninggal dunia, yaitu $44.44 \%$.

Berdasarkan hasil dan pembahasan yang diuraikan, pencegahan terjadinya kecelakaan lalu lintas dapat dilakukan melalui:

1. Sosialisasi kepada kelompok usia 9 sampai 16 tahun dan orang tuanya bahwa kelompok usia tersebut tidak diperbolehkan menjadi pengemudi kendaraan dimana hal ini perlu ditekankan tentang pentingnya kesadaran orang tua untuk memberikan pemahaman dan pengawasan terhadap anak-anaknya. Kelompok usia 9 sampai 16 tahun sebagai penumpang juga perlu diberikan sosialiasasi mengenai kelengkapan dan keamanan sebagai penumpang.

2. Sosialisasi kepada kelompok usia 17 sampai 28 tahun, terutama umur 17 dan 18 tahun mengenai perlunya kesadaran berkendara secara aman dan sesuai dengan peraturan lalu lintas.

3. Perlunya pemberian marka jalan secara jelas dan tanda peringatan di daerah yang merupakan daerah rawan kecelakaan lalu lintas.

4. Perlunya pengaturan lalu lintas setiap pagi di hari kerja karena berdasarkan hasil cluster pada Tabel 7, waktu terjadinya kecelakaan lalu lintas adalah di hari kerja dan di pagi hari. Hal ini sesuai dengan fakta bahwa hari kerja dan pagi hari merupakan waktu dengan kegiatan yang padat.

\section{KESIMPULAN DAN SARAN}

Berdasarkan hasil dan pembahasan terhadap penerapan K-Means Clustering pada data kecelakaan lalu lintas dapat disimpulkan bahwa:

1. Penyebab kecelakaan lalu lintas pada 32 kecelakaan pada dataset adalah karena kesalahan pengemudi.

2. Korban kecelakaan yang paling sering adalah pengemudi dan usia yang paling sering menjadi korban kecelakaan adalah usia 9 sampai dengan 28 tahun. Sedangkan keadaan yang paling sering dialami korban kecelakaan lalu lintas adalah luka ringan.

3. Penerapan K-means clustering telah berhasil dilakukan pada dataset 1 yang divisualisasikan dalam bentuk peta lokasi kejadian.

4. Pengujian silhouette coefficient pada setiap distance measure untuk dataset lokasi kejadian menunjukkan bahwa distance measure paling optimal adalah jumlah cluster sebanyak 4, yakni 0.685351106 .

5. Pengujian silhouette coefficient pada setiap distance measure untuk dataset yang memuat 7 atribut menunjukkan bahwa distance measure paling optimal adalah jumlah cluster sebanyak 2 .

6. Penerapan K-means clustering telah berhasil dilakukan pada dataset 2, dimana kedua cluster yang dihasilkan menunjukkan bahwa kecelakaan lalu lintas sering terjadi pada kendaraan roda 2 , korbannya adalah pengemudi, terjadi pada hari 
kerja, dan terjadi di waktu pagi hari. Namun untuk keadaan korban di cluster 1 didominasi dengan keadaan meninggal dunia, sedangkan keadaan korban di cluster 1 didominasi dengan keadaan luka ringan.

7. Waktu terjadinya kecelakaan dengan peluang terbesar adalah saat hari kerja dan di pagi hari.

Penelitian selanjutnya diperlukan pengumpulan data yang memuat kejadian kecelakaan yang lebih banyak dan mencakup daerah yang lebih luas agar memperoleh keberagaman data sehingga proses clustering lebih optimal. Selain itu, pemilihan centroid awal juga perlu ditentukan menggunakan metode selain simple random sampling.

\section{UCAPAN TERMA KASIH}

Penulis mengucapkan terima kasih kepada Kementerian Riset, Teknologi, dan Pendidikan Tinggi atas bantuan biaya pada skema Penelitian Dosen Pemula Tahun Anggaran 2018.

\section{DAFTAR PUSTAKA}

ANGGARA, M., SUJIANI, H., dan NASUTION, H., 2016. Pemilihan Distance Measure pada K-Means Clustering untuk Pengelompokkan Member di Alvaro Fitness. Jurnal Sistem dan Teknologi Informasi, Vol 1, pp. 1-6.

ANGGODO. Y. P., CAHYANINGRUM, W., FAUZIYAH, A. N., KHOIRIYAH, I. L, KARTIKASARI, O., dan CHOLISSODIN, I., 2017. Hybrid K-Means dan Particle Swarm Optimization untuk Clustering Nasabah Kredit. Jurnal Teknologi Informasi dan Ilmu Komputer (JTIIK), vol. 4,no. 2, pp. 104-110.

FAJAR, M. S., 2015. Analisis Kecelakaan Lalu Lintas Jalan Raya di Kota Semarang Menggunakan Metode K-Means Clustering. Skripsi. Semarang: Jurusan Teknik Elektro Fakultas Teknik Universitas Negeri Semarang.

HAN, J., KAMBER, M., dan PEI, J., 2011. Data Mining: Concepts and Techniques (3rd ed.). USA: Morgan Kaufmann.

HUMAS POLRES TANAH LAUT, 2017. Polres Tanah Laut Bentuk Komunitas Korban Laka Lantas. Tersedia di <http://humasrestala.blogspot.co.id/2017/03/polres-tanahlaut-bentuk-komunitas.html> [Diakses 7 Juni 2017]

ISWARI, L. dan AYU, E. G., 2015. Pemanfaatan Algoritma K-Means untuk Pemetaan Hasil Klasterisasi Data Kecelakaan Lalu Lintas, Teknoin, Volume 21, 1-11.
MAULANA, A., 2017. Angka Kecelakaan Lalu Lintas Tahun Lalu Naik. Kompas. Tersedia di < https://sains.kompas.com/read/2017/01 /25/180500230/angka.kecelakaan.lalu.lintas .tahun.lalu.naik>

[Diakses 6 Juni 2017]

RAHMAT, B., GAFAR, A.A, FAJRIANI, N., RAMDANI, U., UYUN, F.R., PURNAMASARI, Y., dan RANSI, N., 2017. Prosiding Seminar Nasional Riset Kuantitatif Terapan 2017: Implementasi $K$ Means Clustering pada RapidMiner untuk Analisis Daerah Rawan Kecelakaan. Kendari: Lembaga Pengembangan Sistem Informasi Universitas Halu Oleo.

WAHID, M., 2016. Sudah 47 Nyawa Melayang Akibat Kecelakaan Lalu Lintas di Tanah Laut. Tersedia melalui: Banjarmasin Post $<$ http://banjarmasin.tribunnews.com/2016/0 8/22/sudah-47-nyawa-melayang-akibatkecelakaan-lalulintas-di-tanahlaut> [Diakses 6 Juni 2017] 
Halaman ini sengaja dikosongkan 